\title{
Metaforiese elemente in die forensiese taalgebruik van die Johannesevangelie
}

\author{
J G van der Watt en L Voges \\ (Universiteit van Pretoria)
}

\begin{abstract}
Metaphorical elements in the use of forensic language in the Gospel according to John

The metaphorical nature of the forensic material in the Gospel of John, leads to the conclusion that more than one courtcase is actually implied. Parallel to the earthly courtcase of Jesus, a spiritual courtcase, where the roles are reversed, is taking place. From these two courtcases, a third one (also spiritual) develops. In this third courtcase, the real reader has to make a decision - for Jesus or against Jesus?
\end{abstract}

\section{WIE IS JESUS?}

Die outeur van die Johannesevangelie formuleer die doel van sy skrywe soos volg: "Hierdie wondertekens is beskrywe sodat julle kan glo dat Jesus die Christus is, die Seun van God, en sodat julle deur te glo, in sy Naam die lewe kan hê" (Joh 20:31)'. Die Evangelie stel dit duidelik ten doel om Jesus so te beskryf dat die leser Hom as Christus, die Seun van God, kan ontmoet met gevolglik soteriologiese resultate.

Een van die retoriese middele wat die outeur aanwend om Jesus so oortuigend moontlik aan die leser bekend te stel, is die konstante bevraagtekening van Jesus se identiteit deur die loop van die narratief. Aan die een kant word positiewe belydenisse aangaande Jesus se identiteit gegee ${ }^{2}$, maar aan die ander kant word dit afgewissel deur weergawes van onsekerheid en twyfel oor wie Jesus regtig is ${ }^{3}$. Die outeur se kombinering van hierdie

\footnotetext{
I Alle Skrifaanhalings en -verwysings kom vanuit die Nuwe Afrikaanse Vertaling (1983).

2 Jesus gee nie net sterk positiewe belydenisse oor Homself, in die vorm van die "Ek is"- uitsprake $(6: 35,41,48,51 ; 8: 12 ; 9: 5 ; 10: 7,9,11,14 ; 11: 25 ; 14: 6 ; 15: 1,5)$ nie, maar positiewe belydenisse is ook afkomstig vanaf karakters in die Evangelie, o a Johannes die Doper $(1: 26-27 ; 29: 31,34,36)$, Jesus se dissipels $(1: 41,49 ; 20: 28)$, die blinde man (9:33), die Samaritane $(4: 29,42)$ en Nikodemus $(3: 2)$.

${ }^{3}$ Die bevraagtekening van Jesus se identiteit begin alreeds met die gesprek tussen Jesus en Natanael (1:47-50). Hierop volg die gesprek tussen Jesus en die Jode na die genesing van die verlamde man

$(5: 12,18)$. Jesus gebruik laasgenoemde gesprek as 'n geleentheid om oor Homself te getuig. Ook die lang gesprek in hoofstuk 6 handel oor die bevraagtekening van Jesus se identiteit $(6: 41-42,43-51,52,60,66,68-69)$. Hoofstuk 7 skets die intensiteit van die
} 
belydenisse, stel dit opsigself duidelik dat daar verskillende opinies rondom Jesus se identiteit geheers het. Die bevraagtekening van Jesus se identiteit is ' $n$ sentrale retoriese tegniek waarmee die outeur die ware identiteit van Jesus na vore wil bring. Met behulp van bevraagtekening word geleentheid vir korreksies en derhalwe effektiewe en positiewe karakterontwikkeling gebied.

\section{REGSPRAAK IN DIE ANTIEKE JOODSE EN ROMEINSE KONTEKSTE}

"Jesus is constantly engaged in tribulations, which the narrator most frequently portrays as a formal trial or forensic proceeding against Jesus" (Neyrey 1996:107). Met hierdie opmerking verwys Neyrey na die gangbare Romeinse regsplegingproses in die tyd van Jesus. Die verhaal wat in die Evangelie vertel word, speel egter in ' $n$ Joodse konteks af, hoewel die Evangelie waarskynlik vir ' $n$ meer diverse gehoor, wat Grieke, Romeine en Samaritane insluit, bedoel was ${ }^{4}$. Dit maak dit dus nodig om beide die Joodse en Romeinse wyse van regspraak in ag te neem indien forensiese elemente in die Johannesevangelie nagegaan wil word.

\subsection{Joodse regspraak ${ }^{5}$}

2.1.1 Die basis van alle Joodse regspraak was in God self geleë ${ }^{6}$. As Skepper was Hy regter van die heelal (vgl bv Gen 18:25). Sy oordele is finaal en regverdig, omdat Hy self regverdig is en nooit sy eer in onguns sal bring nie ( $v g l$ bv Ps 7:12; 97:2). Daarom was Hy ook die finale Een waarop ' $n$ mens jou kon beroep as die menslike regspraak nie na jou bevrediging verloop het nie?.

In die Johannesevangelie tree bogenoemde motiewe sterk na vore. In Jesus is die waarheid asook die regverdige oordeel teenwoordig $(8: 16)^{8}$. Daarom kan die oordeel presenties bekend en gerealiseerd wees $(3: 18$; 12:48). God is die Een wat finaal besluit en waarop jy jou kan beroep vir

onsekerheid en twyfel wat daar oor Jesus se identiteit geheers het $(7: 5,12,15,20,24$ $28,30-32,40-44,46-49,51)$. Die skerp bevraagtekening van Jesus se identiteit word in hoofstuk 8 en verder voorigesit $(8: 13,22,25,30,48,52,53 ; 9: 16,24,29 ; 10: 33,41 ; 11: 47$ $50 ; 12: 13-15,21,29,34,37-43 ; 18: 33-40 ; 19: 19,21)$.

${ }^{4}$ Vergelyk Thompson (1992:371).

${ }^{3}$ Hier gaan slegs ' $n$ baie oorsigtelike en kort samevatting gegee word van die hooflyne van die proses met die oog op die verdere bespreking van die inhoud van die Johannesevangelie.

${ }^{6} \mathrm{Vir}$ ' $\mathrm{n}$ volledige bespreking van die Joodse regspraak sien Mafico (1997:ad loc), Schneider (1992:363) en Travis (1992:408, 411)

${ }^{7} \mathrm{n}$ Illustrasie van God as die Een wat die finale beslissing neem sien ons in die verhaal van die konflik tussen die Israeliete en die Ammoniete in Rig 10:17-12:7.

${ }^{8}$ In die lig kan Pilatus se ironiese vraag in 18:38 ook soos volg verstaan word, naamlik "Wat is waarheid?" 
regspraak. Dit is wat Jesus konstant doen. Die Jode en Pilatus veroordeel Hom tot die dood, maar in en deur die dood is God by Hom $(8: 29 ; 16: 32)$. Deurdat Jesus uit die dood uit opstaan, toon God wat die ware oordeel behoort te wees $(20: 28)$. God het reg uiteindelik in die teenwoordigheid van onreg laat seëvier. By God lê die ware mag om te kruisig en los te laat (19:10-11).

2.1.2 Die aard van die regspraak was nie primêr daarop gemik om die kwaaddoener te identifiseer en te straf nie - hoewel dit ook gebeur het maar eerder om die verhoudinge binne die verbondsvolk suiwer en reg te hou (vgl bv 1 Sam 7:15; Jer 5:26-29). God sal dus mense straf wat dit vir ander moeilik mak en sosiale billikheid oorboord gooi, al lyk hulle op die oog af godsdienstig vroom (vgl bv Miga 6:7-13).

Hierdie motiewe word ook in die Johannesevangelie aangetref. Jesus se primêre doel in die Evangelie is nie om mense te kom veroordeel nie, maar om die familie van God te kom herstel deur die ewige lewe te gee aan diegene wat glo (1:11-12;3:16-18,36; 5:24; 8:12-19;9:39; 12:47-50). Diegene wat egter nie in Jesus glo nie, sal geoordeel word. Tog is daar nog die geleentheid om in die lig van sy boodskap hulle eie posisie te herstel.

2.1.3 Die regspraak is deur God gedelegeer, sodat ander dit namens Hom kon doen (vgl bv Rig 2:16; 3:9). Hierdie "ander" persoon moes egter in sy regspraak God se heilige en regverdige aard weerspieël (vgl bv Eks 18:17. 22). Die regspraak het op verskillende maniere plaasgevind, van goed georganiseerde regspraak deur die koning, ' $n$ volksverhoor deur oudstes in die poort tot by individuele verhore deur individue wat gesien is as mense met status. Dit kan ' $n$ rede wees waarom die Joodse regspraak ietwat minder formeel gestruktureer was as dié van die Romeine'. Die deurvoer van regspraak het die hele gemeenskap betrek - almal kon by die stadspoort gaan inspraak lewer of meedoen. God was as imminent ervaar, aangesien Hy die bron van alle reg en geregtigheid was. Daarom word daar byvoorbeeld gesê dat as daar ' $n$ regsprobleem is, kan die persoon na die plek toe gaan wat deur God "vir hom aangewys" word en dan is daar direk daarna " $n$ verwysing na die Levitiese priesters en die regter op diens ( $\mathrm{vgl}$ bv Deut 17:8-9). Die "plek wat aangewys word", veronderstel dat waar die verteenwoordigers van die Here is, daar is die "hof". Solank die regter(s) en die betrokkenes saam was, was die situasie geskik vir 'n hofsaak. Lokaliteit is dus nie " $n$ belangrike vereiste vir " $n$ hofsaak om plaas te vind nie.

Ook ten opsigte van hierdie karaktertrekke skiet die Evangelie nie tekort nie. Regspraak word nie alleen aan Jesus gedelegeer nie (5:22), maar ook aan die gelowiges $(3: 19 ; 20: 23)^{10}$. Daarbenewens word Jesus net aan

\footnotetext{
${ }^{9}$ Vergelyk Harvey (1976:46).

${ }^{10}$ Vergelyk Neyrey (1996:110) en Thompson (1992:378)
} 
die einde voor Pilatus (hfst 18) in ' $n$ tipiese Romeinse hof verhoor". Die res van die verhore van Jesus vind, by wyse van spreke, sommer in die strate van Jerusalem plaas (hfste 5, 7-10). Die lokaliteit is nie belangrik of konstituerend vir die hofsaak nie, maar wel die getuies en persone wat die oordeel moet fel' ${ }^{12}$. Dit maak dit vir die outeur van Johannes moontlik om gemaklik "van hofsaak tot hofsaak" te beweeg in sy narratief, aangesien hy nie gebind word deur lokaliteit nie. Daarom kan die outeur van Johannes forensiese elemente deurgaans as retoriese middele deur die Evangelie funksioneel aanwend.

2.1.4 Die wyse waarop regspraak deur die Jode in Jesus se tyd gedoen is, was aan die hand van die Wet $(18: 31 ; 19: 7)^{13}$. Die beginsel dat die maatstawwe wat ' $n$ persoon aan ander stel, ook vir homself moet geld, word ook telkens aangetref (bv Matt 7:1-5 of die sogenaamde "goue reël", waarvan Matt 7:12 ' $\mathrm{n}$ variasie is). Dit het ook ' $\mathrm{n}$ rol gespeel by die teenwoordigheid en optrede van die getuies wat ' $n$ belangrike posisie beklee het in die forensiese prosedure. Harvey (1976:47) toon aan dat 'n Joodse hof gewoonlik nie " $n$ saak gaan ondersoek het nie. Daarom was die betroubaarheid, eerlikheid en posisie van die getuies van groot belang in die vasstel van wat werklik gebeur het. Slawe of vroue is dus gewoonlik nie in die proses toegelaat nie ${ }^{14}$. Die voorskrifte van die wet was dat daar ten minste twee getuies teenwoordig moes wees en dat een persoon, veral as dit die persoon self is, nie voldoende is om die proses te laat voortgaan nie ( $\mathrm{vgl}$ bv Num 35:30; Matt 18:16; Joh 5:31; 18:13,17).

Hierdie Joodse momente kom ook in die Evangelie voor. Jesus is die Een wat die Wet waar maak $(1: 17,45)^{15}$. Daarom tree die Jode wat glo dat hulle God se wil doen deur Jesus te wil doodmaak (16:2), ironies genoeg eintlik teen die Wet op $(7: 19-23)^{16}$. Hierdeur toon Jesus aan dat hulle wyse van benutting van die wet eintlik verkeerd is (5:39-40). Daarmee plaas hulle hulleself eintlik in die beskuldigdebank. Die oordeel wat hulle oor

1 Sien Blinzler (1961:165), Catchpole (1971:254), Corley (1992:851) en SherwinWhite (1963:41-42) vir ' $n$ volledige beskrywing.

12 Daar is meer waarde aan ' $n$ persoon en sy getuienis geheg, omdat 'n getuienis gesien is as ' $n$ toets vir die persoon se reputasie, waarde of status - in kort as ' $n$ toets vir " $n$ persoon se eer. Vergelyk Malina (1993:27) in die verband.

${ }_{3}^{3}$ Profete, soos Moses, was onder andere verantwoordelik vir die gee van wette. Hulle het as agente vir God gefunksioneer (vgl bv Deut 4:8, 44; Jer 26:4-5; Klaagl 2:9; Neh $8: 1,8,14)$.

14 Dit maak die proses in Johannes so merkwaardig. Die Samaritaanse vrou (hfst 4), asook byvoorbeeld Maria Magdalena (20:18) word sterk getuies vir Jesus. Maar Jesus het ook ander getuies wat selfs die belangrike getuienis van iemand soos Johannes die Doper onnodig maak (5:33-36).

is Jesus spreek Homself telkens baie positief teenoor die gesag van die wet uit, byvoorbecld $8: 17 ; 10: 34 ; 12: 34 ; 15: 25$.

${ }^{16}$ Vergelyk Corley (1992:847-848). 
Jesus fel, naamlik dat Hy vanweë laster moet sterf (18:30; 19:7), geld dus nou ook vir hulle.

Jesus lê ook baie klem op die kwaliteit van sy getuies, byvoorbeeld in hoofstuk 5 waar Hy nie eers van Johannes die Doper as getuie gebruik wil maak nie, maar God, sy dade en die Skrif as getuies inroep. In 8:14 is daar ' $n$ verdere interessante opmerking naamlik dat Hy self as getuie kan optree, bloot vanweë die aard van sy identiteit. Hy kom van God af en daarom is sy getuienis waar. Hy het integriteit.

So reflekteer die Evangelie voortdurend Joodse forensiese elemente in die ontwikkeling van die argument.

\subsection{Romeinse regspraak ${ }^{17}$}

Neyrey (1996:109) toon in ' $n$ nuttige tabel aan dat heelwat oor die Romeinse juridiese proses vanuit Jesus se hofsaak voor Pilatus geleer kan word:

\begin{tabular}{|c|c|c|c|}
\hline $\begin{array}{c}\text { Forensiese } \\
\text { Elemente }\end{array}$ & Lukas 23:14-15 & Johannes 18:1-19:4 & Johannes 19:5-16 \\
\hline Arrestasie & $23: 14 a$ & $18: 1-11$ & - \\
\hline Aanklagte & $23: 14 b$ & $18: 29-30$ & $19: 7$ \\
\hline Regter se cognitio ${ }^{18}$ & $23: 14 c$ & $18: 33-38$ & $19: 8-11$ \\
\hline Oordeel & $23: 14 d$ & $18: 39$ & $19: 12$ \\
\hline Vonnis & $23: 15 b$ & $19: 4$ & $19: 13-16$ \\
\hline $\begin{array}{l}\text { Juridiese } \\
\text { waarskuwing }\end{array}$ & $23: 15 \mathrm{c}$ & $19: 1-4$ & - \\
\hline
\end{tabular}

Neyrey $(1996: 110,116)$ argumenteer dat hierdie formele juridiese elemente ook kenmerkend van die proses in hoofstuk 7 is:

\begin{tabular}{|l|c|}
\hline \multicolumn{1}{|c|}{ Forensiese elemente } & Johannes 7:1-51 \\
\hline "Gepoogde" arrestasie & $7: 20,32,44-46$ \\
\hline $\begin{array}{l}\text { Aanklagte teen Jesus: Valse profeet en } \\
\text { verbreker van die Sabbatswette }\end{array}$ & $7: 12-18,21-24,41-49$ \\
\hline $\begin{array}{l}\text { Die regters: Fariseërs, Hoëpriesters en } \\
\text { Joodse opponente }\end{array}$ & $7: 13,15,32,45-52$ \\
\hline Getuienis vir en teen Jesus & $7: 12,16-18,21-24,27,41-42,46$ \\
\hline
\end{tabular}

${ }^{17}$ In die lig van die werk wat reeds deur onder andere Neyrey (1987:509-542; 1996: 107-124) in die verband gedoen is, gaan die Romeinse prosedure nie hier volledig herhaal of bespreek word nie. ' $n$ Kort opsommende weergawe is voldoende.

${ }^{18}$ Sien Corley (1992:853) en Sherwin-White (1963:13-23) se beskrywing van hierdie begrip. 


\begin{tabular}{|l|c|}
\hline $\begin{array}{l}\text { Die cognitio van die regters se ondersoek } \\
\text { na Jesus of Jesus wat die ander oordeel }\end{array}$ & $7: 14-15,28-29,37-43$ \\
\hline 'n Skuldige oordeel word geimpliseer & $7: 30,44$ \\
\hline Doodsvonnis word in vooruitsig gestel & $7: 1,29,34$ \\
\hline Instruksies oor wettige juridiese oordele & $7: 24,51$ \\
\hline
\end{tabular}

Laastens toon Neyrey (1996:109) aan dat daar in hoofstukke 7 en 8 verskeie formele ooreenstemmings tussen die elemente is wat tipies van die forensiese proses is. Hy kom tot die konklusie dat "the entire story of Jesus should be read in terms of an extended forensic process." (1996:116).

Twee opmerkings moet hier gemaak word:

(i) Neyrey is korrek in hierdie waarneming, maar het nie genoeg ruimte gelaat vir die Joodse prosedures in die uitwys van die forensiese elemente nie. Daar word nie net met die elemente van of die een of die ander gewerk nie, maar met beide ${ }^{19}$.

(ii) Deur die hele Evangelie tref ' $n$ mens forensiese aspekte aan wat aangewend word om die identiteit van Jesus te beredeneer en op onbetwyfelbare basis te plaas ${ }^{20}$. Destyds, soos vandag, moes die reg en oordeel van die hof gerespekteer word (vgl bv Deut 17:11-13). Plekke waar daar byvoorbeeld van forensiese middele gebruik gemaak is in die narratief is hoofstukke 1819 waar Jesus verskyn voor die Jode (Annas en Kajafas) en voor Pilatus; Jesus wat getuies inroep in 5:31,36; die konflik in hoofstukke 7-8 wat in forensiese taal aangebied word; Jesus wat homself beskerm in 10:22-29 en wat in 11:45-53 in absentia geoordeel word, asook die gebeure in hoofstuk 9. ${ }^{21}$ Die Heilige Gees tree ook as getuie op (16:8-11) $)^{22}$. Forensiese taal en motiewe word inderdaad deur die hele Evangelie aangetref. ${ }^{23}$

\footnotetext{
${ }^{19}$ Vergelyk ook Corley $(1992: 851)$ in die verband.

${ }^{20}$ Vergelyk Harvey (1976:93-95).

${ }^{21}$ Daar gaan nie detailaandag aan al hierdie perikope gegee word nic. Die aanwesigheid en aard van die forensiese taal en motiewe gaan alleen aangetoon en geïllustreer word.

${ }^{22}$ Vergelyk Turner (1992:349).

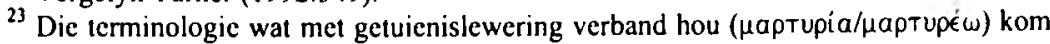
in oor die 30 verse in die Evangelie voor, terwyl kpioıs/kpivetv omtrent 25 maal voorkom. In hoofstukke 5 en $7-8$ in besonder word forensiese taal gebruik. Die

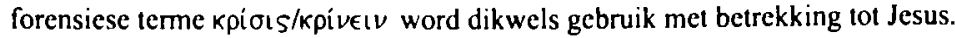




\subsection{Twee hofsake}

In die res van hierdie artikel gaan die fokus val op die metaforiese benutting van forensiese aspekte in die Evangelie ${ }^{24}$. Die basiese tese wat beredeneer gaan word, is dat daar parallel met die aardse hofsaak tegelyk 'n hemelse hofsaak afspeel. Die belangrikste karakters is akteurs in beide hofsake, maar vanweë die onvermoë van die opponente van Jesus om die geestelike of goddelike werklikheid raak te sien, is hulle onbewus van hulle eie rol, asook die unieke rol van Jesus en die Vader in die geestelike hofsaak. Die geestelike of goddelike hofsaak is egter die hofsaak wat tel, aangesien God self verantwoordelik is vir die oordeel in die hofsaak (vgl afd 2.1).

Die geestelike hofsaak ontwikkel analoog met die aardse hofsaak. Die karakters in die twee hofsake beklee egter verskillende posisies - die aanklaers in die een word die beskuldigdes in die ander en omgekeerd. Die oordele verskil dienooreenkomstig. Tog is die gebeure in die twee hofsake vervleg. Die gebeure en keuses wat in die aardse hofsaak gemaak word, bepaal inderdaad die uitslag van die geestelike hofsaak. Die basiese patroon waarop die metaforiese aard ontvou kan skematies so voorgestel word:

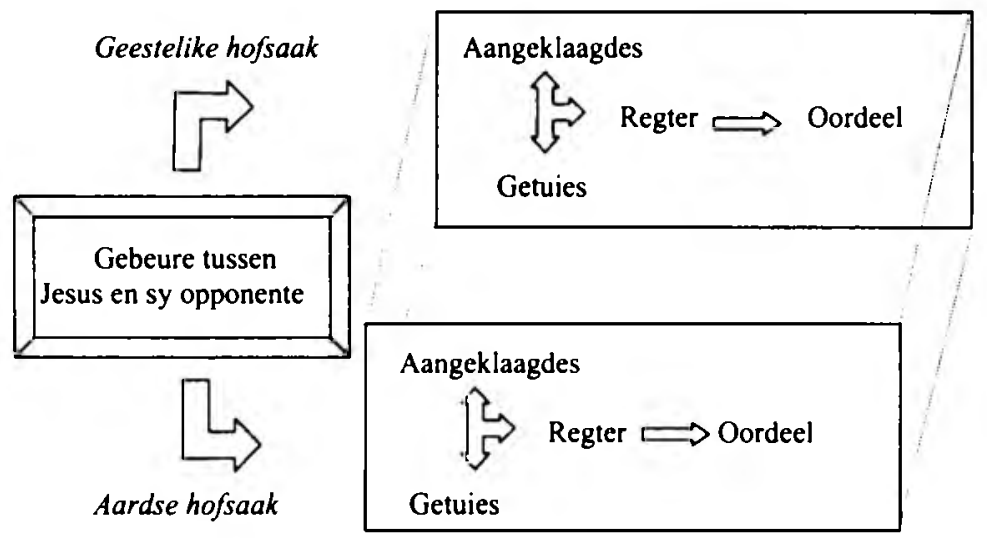

\footnotetext{
${ }^{24} \mathrm{Vir}$ ' $\mathrm{n}$ volledige uiteensetting van wat met metafories bedoel word, sien Van der Watt (2000:6-22). Wat hier daarmee verstaan word, is dat daar 'n figuurlike realiteit analogies met ' $n$ letterlike realiteit ontwikkel word. Die figuurlike realiteit beskryf die transendente wêreld waarmee die mense in die Johannesevangelie gekonfronteer word.
} 


\subsection{Voorbeelde van hofsake}

Die wyse waarop die forensiese elemente in die Evangelie benut word varieer. Ten einde die variasie te illustreer gaan enkele voorbeelde gegee word waar daar binne kontekstueel afgeronde gedeeltes sterk van forensiese elemente gebruik gemaak word ${ }^{25}$. Op spesifieke kontekste gaan nou gefokus word. Die metaforiese aard van die forensiese taalgebruik en motiewe $^{26}$ sal aan die hand van 5:17-47, 8:13-59 en hoofstukke 18-19 geîllustreer word, en dan sal daar kortliks geïllustreer word hoe van die Joodse juridiese elemente in die breë in die Evangelie benut word ${ }^{27}$.

\subsubsection{Die gebeure in hoofstuk 7 en 8 as illustrasie van die benutting van die forensiese materiaal}

Die forensiese proses begin in hoofstuk 7 en word voortgesit in hoofstuk 8 . Dit wil dus voorkom of Jesus se opponente Nikodemus se wetlike raad in 7:51 in hoofstuk 8 navolg en dus eers wil luister na Jesus en uitvind wat Hy doen, om daarna tot ' $n$ oordeel oor Hom te kom. Die proses verloop soos volg:

Jesus getuig aangaande Homself en sy identiteit (8:12). Die Fariseërs betwyfel egter hierdie selfgetuienis van Jesus omdat die getuienis van 'n persoon oor homself nie in regspraak geldig is nie (8:13). Jesus staan die juridiese tegnikaliteit teë deur na sy sending te verwys. Sy getuienis is inderdaad waar, aangesien Hy weet van waar Hy kom en waarheen $\mathrm{Hy}$ oppad is $(8: 14,23)^{28}$. Die vlees en kosmos staan in kontras tot die hemelse of geestelike realiteit, net soos die oordeel volgens die vlees in kontras staan tot Jesus se oordeel (8:15-16).

Soos hierbo bespreek was die aard en integriteit van die getuie van groot belang in die bepaling van die waarheid in ' $n$ Joodse hofsaak. As die getuie betroubaar is, is die getuienis deurslaggewend. Jesus kom van bo wat ideologies krities in die antieke wêreld van Johannes op die belangriker, goddelike sy van die werklikheid dui. Dit word onderstreep deur die Vader wat saam met Hom getuig, wat hulle getuienis in 'n hof geldig maak, want daar is inderdaad twee wat nou getuig $(8: 17-18)$.

${ }^{25}$ Toe die Joodse en Romeinse regspraak bespreek is, is daar immers reeds verwys na die gebruik van forensiese elemente en veral in die geval van die Joodse regspraak is daar gewys hoe dit in die algemeen in die Evangelie voorkom.

${ }^{26}$ Daar word verskeie male van vonnis of oordeel gepraat in hoofstukke 7-9.

${ }^{27}$ Vanweë die lengte van die artikel word dit nie volledig gedoen nie, maar dien alleen as illustrasie.

${ }^{28}$ Jesus tree op as God se "agent". Dit beteken dat die Een wat gestuur is, is soos die Een wat Hom gestuur het. Die een wat gestuur word, verteenwoordig die status en gesag van die cen wat hom stuur. As Jesus die boodskap van die Vader bring en daardie boodskap is waar, is Jesus se boodskap ook natuurlik waar. Vergelyk Thompson (1992:377) in die verband. 
Maar die twee is nie net getuies nie, maar ook regters. In $8: 16$ sê Jesus dat as Hy oordeel, sy oordeel reg en geloofwaardig is $(8: 24,26)$. In terme van die aardse hofsaak is hulle dus getuies, maar in terme van die hemelse hofsaak is hulle regters ${ }^{29}$. Hulle dubbele rol is moontlik omdat daar ' $n$ dubbele hofsaak is wat sigself afspeel.

Die dinamiek van die metafoor is duidelik. Jesus en die Vader is die werklike getuies, maar ook die werklike regters. Die geïmpliseerde leser weet dat die Vader God is. Daarom is die Vader en die Seun se getuienis waar, aangesien Hulle die waarheid is. Wie dit begryp, begryp dat daar ' $n$ tweede geestelike hofsaak besig is om af te speel. Juis hier lê die kortsluiting. Die opponente van Jesus is nie bewus van die tweede of geestelike hofsaak nie, want hulle ken nie Jesus nie en ook nie die Vader nie (8:19), wat eintlik impliseer dat daardie getuienis binne hulle verwysingsraamwerk as mense van hierdie wêreld $(8: 23)$ nie geldig is of kan wees nie. Die primêre getuie in die hemelse hofsaak is onsigbaar. Kenteoreties kan iemand mos nie ' $n$ getuie in 'n hofsaak in ag neem as hy nie daardie getuie ken nie ${ }^{30}$. Juis daarom kan die Fariseërs nie verstaan nie, want hulle kan net volgens vleeslike, aardse maatstawwe redeneer - hulle snap dus nie die juridiese verloop en getuienis van die geestelike hofsaak nie (8:27). Slegs die aardse hofsaak is vir hulle " $n$ werklikheid.

Hoofstuk 8:21-58 ontwikkel op die basis van beskuldiging, verduideliking en teenbeskuldiging. Die patroon vanaf 8:31 toon die ontwikkeling van die geding tussen Jesus en sy opponente aan.

(i) Die beskuldigings: Op Jesus se stelling in 8:32, antwoord die Jode met ' $n$ teenstelling wat ' $n$ vraag insluit (8:33). Jesus se aanvanklike stelling geld dus nie. In reaksie op Jesus se verduideliking (8:34-38) verdedig die Jode hulleself (8:39). Op grond van hulle gedrag betwyfel Jesus egter hulle Abrahamitiese herkoms (8:39-41), waarop hulle hulle verder op hulle kindskap van God beroep (8:41). Dit is hulle hoogste argument en behoort Jesus se beskuldiging verkeerd te bewys. Wat hier gebeur is dus interessant: Jesus plaas die Jode in die beskuldigde bank - hulle is op die verdediging. Hierteenoor is die Jode se argumente weer daarop gemik om Jesus as ' $n$ valse getuie uit te wys.

${ }^{29}$ In 5:22, 27 word reeds gesê dat die Vader die oordeel aan die Seun gegee het. Die Seun oordeel egter in ooreenstemming met wat die Vader van Hom verwag (5:30) en daarom is sy oordeel ook regverdig. Tog val die klem met sy sending nie op die oordeel nie, maar op die feit dat Hy die ewige lewe aan mense bring (3:17). Tog stel sy koms mense onwrikbaar voor ' $n$ keuse wat vir sommige wat nie in Hom wil glo nie, oordeel beteken $(3: 18 ; 12: 47-48)$.

${ }^{30}$ Die vlak van hulle onkunde word verder uitgedruk deur hulle misverstand in 8:22 waar hulle Jesus se woorde dat Hy weggaan in terme van selfmoord interpreteer. 
(ii) Die oordele: Jesus kom dan met ' $\mathrm{n}$ goedberedeneerde oordeel na aanleiding van die gesprek: juis die getuienis van sy opponente oortuig Hom dat hulle nie kinders van God is nie, maar van Satan (8:42-47). Hulle ken God nie wat blyk uit die feit dat hulle die getuienis van Jesus nie wil aanvaar nie. Die opponente van Jesus laat nie op hulle wag nie. Onmiddellik spreek hulle hulle oordeel ook uit: Jesus is ' $n$ Samaritaan en van die duiwel besete $(8: 48)$. Die twee groepe se oordeel oor die ander kom beide op dieselfde neer. Die ander een staan nie aan God se kant nie, maar aan die kant van die duiwel.

(iii) Die konsekwensies van die oordeel: Wie mag egter regtig hier die rol van die regter inneem? In 8:49-51 verdedig Jesus homself, maar hierdie keer uit die posisie van gesag - deur Hom so te beledig is sy opponente besig om die Regter - sy Vader - asook Homself oneer aan te doen. Daarmee onderstreep hy hulle verlore posisie voor die Regter en moedig hulle dus aan om sy woorde te glo en so die oordeel (om te sterf) vry te spring (8:51). Die positiewe aanmoediging strook met die rol van die Joodse regter om verkeerde verhoudinge eers te probeer regstel eerder as om sommer voor die voet te veroordeel. Jesus het self mos immers nie gekom om te oordeel nie, maar om te red.

(iv) Die outensiteit van Jesus se oordeel word betwyfel: In reaksie analiseer die Jode egter Jesus se woorde en val Hom nog meer verbete met allerlei argumente aan en beskuldig Hom van hubris (8:52-53). Hulle aanvaar weer eens nie wat Jesus sê nie, al het Hy hulle gewaarsku dat hulle die Regter beledig (8:49-50). Daarom bevestig hulle weer eens hulle oordeel dat Jesus van die duiwel besete is. Hulle bevraagteken dan ook sy identiteit - Hy is nie groter as Abraham nie. Abraham en die profete is almal dood. Hoe kan Jesus sommer sê dat Hy kan sorg dat mense nooit sal sterwe nie?

(v) Jesus verduidelik die raamwerk van die groter hofsaak: In 8:54-56 keer Jesus nou terug na die begin van die gesprek. Hy sê reguit dat sy Vader wat saam met Hom getuig (8:16-19), dieselfde Persoon is as die God wat sy opponente beweer hulle aanbid. Die opponente ken hierdie God egter nie en kan daarom nie sy getuienis aanvaar nie ${ }^{31}$.

Aan die begin van die gesprek het Jesus ook sy eie getuienis verdedig op grond van sy herkoms en identiteit - Hy het gesê dit legitimeer sy getuienis (8:14). Nou beskryf hy sy herkoms - Hy is pre-eksistent en daarom kon Abraham sy koms verwag, sien en daaroor bly wees (8:56-58). Sy getuienis is dus groter en belangriker as die aartsvader Abraham s'n. Die woorde

${ }^{31}$ Hoofstuk 8 bevat verskeie forensiese bewyse dat Jesus se opponente nie vir God ken nie: 8:19-20, 27 en 43 . 


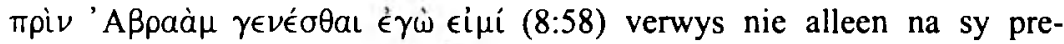
eksistensie nie, maar die $\dot{\epsilon} \gamma \dot{\omega} \in \dot{\epsilon} \mu$ í het goddelike ondertone.

Die opponente het egter hulle oordeel gefel en wil dit tot uitvoering bring (8:59). Die Joodse gebruik was dat daar toegesien moes word dat ' $n$ oordeel wat gefel is, uitgevoer moes word.

Daarmee is nie net die Jode se oordeel gefel nie, maar ook Jesus s'n. Die Jode wil Jesus doodgooi en so bewys hulle hulleself as kinders van die duiwel, die vader van die dood (8:44). Jesus se uitspraak bied lewe deur sy woorde, maar dra ook die klanke van onheilspellende oordeel daarmee saam (8:53 gelees saam met 8:12 wat as inleiding vir die "hofsaak" geld)

Die vervlegting van die twee forensiese prosedures blyk duidelik uit hierdie gedeelte. Jesus is op die beskuldigdebank van die Jode as ' $n$ valse getuie; Jesus se opponente is op die regbank as mense wat God nie ken nie. Die opponente fel hulle oordeel volgens die uiterlike, aardse maatstawwe (8:15), terwyl Jesus sy oordeel fel volgens die goddelike maatstawwe van sy Vader $(8: 26-29)^{33}$. Albei se finale oordeel spel vir die ander party die dood uit. Die aanklaers van Jesus word in hulle gesprek die aangeklaagdes - volgens hulle eie kriteria het hulle hulleself veroordeel omdat hulle nie die figuurlike aard van hierdie forensiese toetsing verstaan het nie. ' $n$ Reël in die Joodse regspleging, soos ons vroeër gesien het, was dat die maatstawwe wat jyself aanwend ook vir jouself moet geld. Die Jode wil Jesus doodmaak (8:59) omdat Hy Homself met Abraham durf vergelyk as iemand wat groter is as Abraham. Hy is van die duiwel. Deur die waarheid nie raak te sien nie, word hulle egter self lasteraars teen God. Iemand wat hom of haarself teenoor God durf stel moet sterf - dit is hulle eie oordeel, wat ook van hulleself sal moet geld.

' $n$ Legitieme vraag is of hier regtig in terme van hofsake of forensiese elemente geredeneer word. Is dit nie maar ' $n$ normale gesprek nie?

\footnotetext{
32 Onvermydelik word Jesus en sy teenwoordigheid ook die locus en modus van die

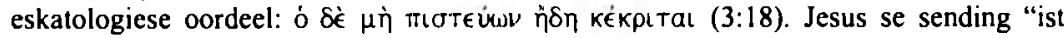
das Gericht" (Bultmann 1978:112). Ewige lewe, wat Jesus gee, word die teenoorgestelde pool van oordeel van die ongelowige (5:24). Die verlore situasie van die ongelowige word beskryf in terme van daardie persoon se stukkende of non-eksistente verhouding met God. So word oordeel dus die manier om die Vader se verwerping van ' $\mathrm{n}$ persoon wat Jesus verwerp het, te beskryf Dit is hoekom Jesus ook Regter genoem kan word of die Een aan wie die reg deur sy Vader gegee is om te oordeel $(5: 22 ; 8: 16)$. Volgens 12:31-32 val die tyd van die oordeel en die kruisgebeure saam. Die Parakleet (16:11) bevestig Jesus se oordeel.

${ }^{33}$ Neyrey (1987:538) sề dat dit bevestig word deur die feit dat Jesus se opponente behoort aan ' $n$ wêreld wat heeltemal die teenoorgestelde is as dié van Jesus: "he is 'from above', while they are 'from below'; he is 'not of this world', while they most surely are 'of this world'..."
} 
Die gebruik van forensiese terminologie (byvoorbeeld $\kappa \rho i ́ \sigma \varsigma s / \kappa \rho i v \in \iota{ }^{34}$

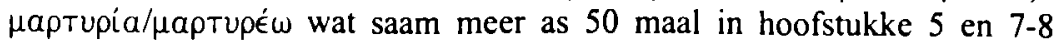
voorkom), die gesprek oor die getuienis wat gelewer word en die aard daarvan, asook die oordeel wat gefel word met die uiteindelike poging om die oordeel deur steniging te voltrek, dui aan dat ons hier met 'n hofsaak en met tipiese forensiese elemente te doen het.

\subsubsection{Jesus roep sy getuies in (5:17-47)}

Nadat Jesus die lam man op die Sabbat genees het, het die Jode besluit om Jesus dood te maak (5:18). In 5:19-29 verweer Jesus Homself deur sy reg en vermoë om op die sabbat iemand te genees aan sy verbondenheid aan die Vader en die Vader se gawes aan Hom toe te skryf. ${ }^{35}$ In 5:31-32 bevind die leser hom of haarself midde in die konteks van 'n hofsaak, maar een waarin die rolle van beskuldigdes en regters ineenvloei ${ }^{36}$. In die twee hofsake wat gelyktyding afspeel word die rolle van die regters en die beskuldigdes omgekeer. Hoewel die Jode Jesus as beskuldigde wil doodmaak $(5: 16,18),{ }^{37}$ word Hy die een wat hulle as skuldiges oordeel.

In die aanloop tot 5:31-47 word Jesus as Regter vanuit goddelike perspektief gevestig $(5: 22,27)^{38}$, want die Vader het die oordeel geheel en al aan Hom oorgelaat. Jesus is die Een wat regverdig oordeel, omdat Hy dit doen volgens die voorskrifte van die Vader $(5: 30)^{39}$. Maar hierdie Regter wat deur sy opponente in die beskuldigdebank geplaas word, verhang die bordjies in 5:31-47 4 .

Allereers word daar aandag gegee aan Jesus as die beskuldigde, wat veral tot by $5: 40$ ontwikkel word. Hy staan as beskuldigde wat volgens die Jode nie soos sy Vader mag werk nie (5:17), aangesien so 'n bewering neerkom op 'n godslasterlike poging om Hom met God gelyk te probeer stel (5:18). Sy identiteit word ontken. Jesus verweer Homself (5:19-30), maar erken die regsimplikasies van selfgetuienis. Hy getuig nie oor Hom-

\footnotetext{
34 Volgens Brown (1971:134) kan kpivw as "judge" of "condemn", vertaal word, afhangende van die konteks. Barrett (1978:216-217) wil die betekenis in die Evangelie beperk tot "condemn", sodat dit die teenoorgestelde van redding verwoord.

35 "The significance the evangelist sees in the Sabbath work is presented as the explanation (justification) of the 'work': Jesus is the Son of God, therefore he must work on the Sabbath." (Pancaro 1975:16).

${ }^{36}$ Stibbe (1993:80) identifiseer 5:16-47 as forensies op grond van die gebruik van kpioıs en $\mu$ aptupia en derifate in hierdie konteks.

${ }^{37}$ Hulle snap nic Jesus se identiteit nie ( $\left.5: 18\right)$.

38 Ashton (1991:335-373) bespreek die Seun van Mens as regter. Hy interpreteer die konsep teen die agtergrond van Daniël 7. Sien ook Moloney (1998:180) en Thompson (1992:379).

${ }^{39}$ Sien Ashton (1991:220-226).

${ }^{40}$ Sien Malina \& Rohrbaugh (1998:109). Neyrey (1996:108) wys verder daarop dat dieselfde gebeur in hoofstukke 7-8.
} 
self nie (5:31), want dit is nie geldig nie, behalwe in sekere gevalle soos waar die identiteit van die betrokke persoon bo alle twyfel staan. In hierdie geval word daardie identiteit juis betwyfel. Jesus roep nou sy getuies in om die waarheid van sy getuienis te bevestig: Die getuienis is sy dade wat $\mathrm{Hy}$ in ooreenstemming met die wil van die Vader uitvoer (5:36), sy Vader self (5:37) en die Skrif (5:38-40). Johannes die Doper het ook van Jesus getuig, maar Jesus het nie eers sy getuienis nodig nie (5:33-35) ${ }^{4}$. Twee of drie getuienis in ' $n$ Joodse hof was genoeg - die uitspraak behoort bo alle twyfel vas te staan. Die aard van die getuienis onderstreep die metaforiese aard van die hofsaak waarin Jesus onskuldig bevind word. Die Vader se stem het niemand nog gehoor of gesien nie. Hy is die onhoorbare en onsigbare getuie. Tog gaan sy teenwoordigheid sigbaar word aan die kruis waar Hy Jesus nie alleen sal laat nie (16:32). Jesus se werke is die dinge wat die Vader Hom gestuur het om te doen. Volgens 5:21 moet Jesus lewe kom gee, wat reeds uit die genesing van die lam man in 5:1-17 duidelik blyk. In hierdie geestelike hofsaak word hierdie dade gepersonifieer as getuie. En dan is daar die Skrif wat oor Jesus getuig (5:39). Ook hierdie is nie direkte getuienis nie - die Skrifte moet ondersoek word (5:40).

Die Joodse opponente snap egter nie die getuienis, Jesus se woorde (5:47) of die hofsaak nie. Die rede is dat hulle nie meer liefde vir God in hulle lewens het nie (5:41), nie God se eer soek nie (5:44) en nie God se Gestuurde aanvaar nie. Hulle soek hulle eie eer wat op menslike vlak alleen lê $(5: 43)$. Soos in hoofstuk 8 verhoed hierdie menslike oriëntering hulle om die geestelike hofsaak raak te sien.

In 5:45-47 beskryf Jesus die verdere verloop van hierdie hofsaak. Moses, wat vir hulle die wet gegee het waarvolgens hulle Jesus nou veroordeel, gaan hulle aankla ${ }^{42}$. Dieselfde woorde wat hulle teen Jesus gebruik, getuig eintlik van Hom, maar hulle besef dit nie en juis dit gaan die klag teen hulle wees en bly. Moses het immers self van Jesus geskryf (5:46). Die Joodse opponente dink dus hulle hou die wet, maar nie een van hulle doen dit nie (7:19). Die Regter is die Vader (5:45), terwyl die Een wat die oordeel fel Jesus is (5:22). Soos Hy by die Vader gehoor het, sal Hy oordeel (5:30). Dat daar dus twee hofsake in hierdie gedeelte gelyktydig afspeel waarin die rolle omgeruil word, is duidelik.

\footnotetext{
${ }^{41}$ Neyrey (1996:110) onderstreep dat heelwat aandag gegee is aan die sosiale status van die getuies as bewys van hulle betroubaarheid. Harvey (1976:45) sê verder: "The case of Jesus, as presented before his contemporary judges, rested upon the word of one witness only: Jesus himself."

${ }^{42}$ Vergelyk Duke (1985:128).
} 


\subsubsection{Die verhoor van Jesus}

Dieselfde figuurlike benutting van forensiese elemente word ook gevind in die verhaal van die kruis en opstanding in hoofstukke 18-203. Die ironie wat hierdie hofsaak omhul word in 19:10-11 treffend uitgedruk: Pilatus waarsku vir Jesus dat hy, Pilatus, die mag het om of vir Jesus vry te laat, of om Hom te kruisig $(19: 10)$. Jesus se antwoord $(10: 17-18 ; 19: 11)$ plaas egter alles in perspektief: Jesus verduidelik dat die Vader Hom die mag gegee het om sy lewe af te lê en om dit weer op te neem ${ }^{44}$.

Dit bevestig sy posisie as Regter en Koning. Jesus word immers op verskeie vlakke as koning geïdentifiseer ${ }^{\mathrm{A}}$. Sy koninkryk is egter nie van hierdie wêreld nie (18:36). Die verteenwoordiger van die wêreldse koninkryk staan voor Hom in die persoon van Pilatus. Hy moet ' $n$ oordeel fel, maar die een wat dit eintlik doen is Jesus. Hy het die mag van God ontvang. Op die menslike vlak van die Jode en Pilatus lyk dit dus vir hulle of hulle die aanklaers en regters is, maar op figuurlike vlak is hulle die aangeklaagdes, in diens van ' $n$ aardse keiser (19:15), op soek na die waarheid (18:38). Die werklike Regter is besig om hulle aan te kla van presies dit wat hulle Hom van beskuldig. Hulle oordeel gaan wel aan die kruis uitgevoer word, maar die wat nie in Jesus glo nie, sal die ewige lewe nooit sien nie - ' $n$ meer verdoemende oordeel.

Hierdie ironiese situasie word verder op verskeie maniere in hierdie gedeelte beklemtoon. Jesus, die beskuldigde, is ooglopend in beheer van sy eie bestemming (18:4-7,8,11,20,23,34,37-39;19:3-4,6,14-15,19,21). Dit dui daarop dat die forensiese materiaal in die Evangelie metafories van aard is. Die hofsaak is iets anders as wat dit lyk. Dit vind plaas op 'n figuurlike vlak met verskillende regters, veroordeeldes en hofprosedures. Die vraag van Pilatus oor wat die waarheid is, het ook ' $n$ ironiese klank (18:38) volgens die Joodse reg bepaal God, as regter, die waarheid. Dit sal uit die kruisgebeure ook blyk. Jesus sterf as die Koning onder ' $n$ ironiese titel wat juis die goddelike waarheid bevat wat almal wat nie glo nie sal veroordeel $(19: 21)^{46}$. 'n Skematiese voorstelling van wat op forensie vlak gebeur, beklemtoon die dinamiek van die figuurlike en ironiese dimensies. Eerstens sal die hofsaak vanuit die oogpunt van die wat "onder/van die wêreld" is voorgestel word:

\footnotetext{
${ }^{43}$ Daar gaan nie hier ' $n$ gedetailleerde uiteensetting van al die forensiese elemente wat in hoofstukke 18-20 ' $n$ rol speel, gegee word nie. Die doel van hierdie beskrywing is net om te illustreer hoc die figuurlike hofsaak in hierdie hoofstukke aangebied word.

${ }^{44}$ Vergelyk Duke (1985:133-134) se verduideliking van hierdie ironie.

4s Die term koning word dikwels deur die betrokke karakters by die kruisgebeure aangetref: Pilatus in 18:33, 37,39; 9:14, 15b, 19; die soldate in 19:3; die Jode in 9:12, 15a, 19; die priesterhoofde van die Jode in 9:21.

${ }^{46}$ Vergelyk Duke (1985:136) se bespreking van die ironiese titel "koning van die Jode".
} 


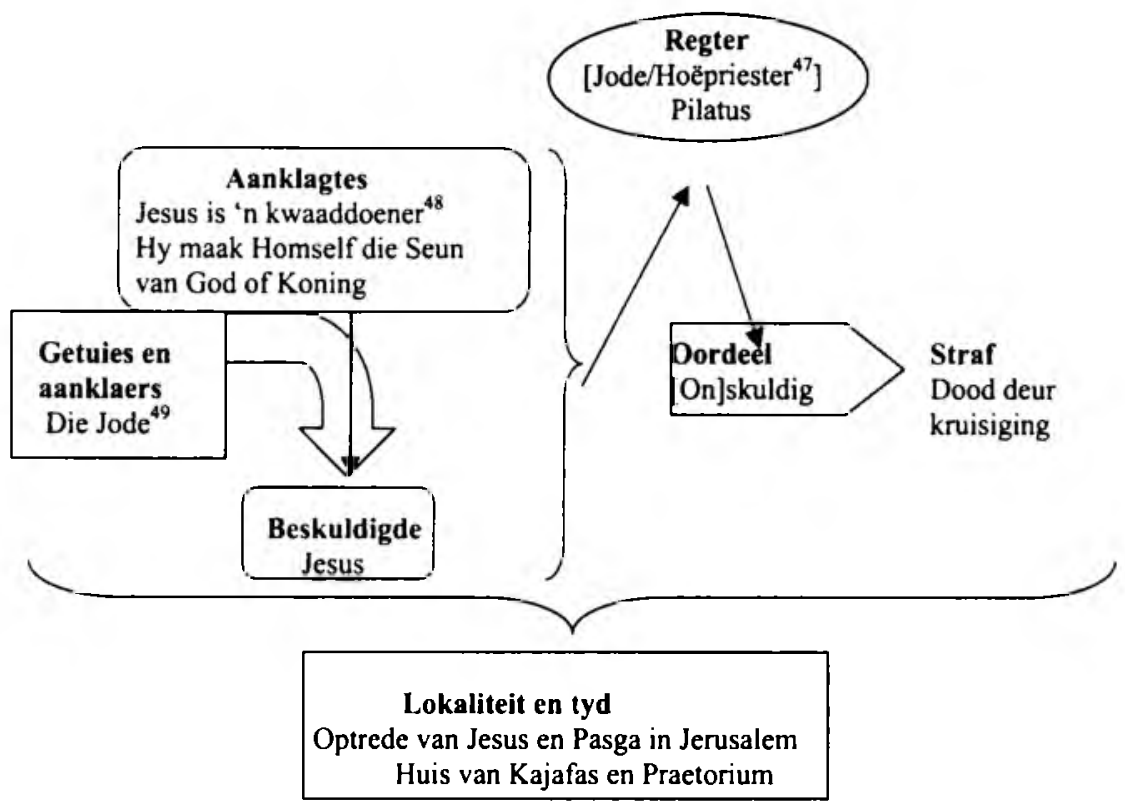

Die skema wys dat die Jode vir Jesus beskuldig van laster en oortreding van die wet. Dit loop uit op die dood aan die kruis. Vanuit aardse perspektief lyk die prosedure in orde, behalwe vir die finale uitslag deur die aardse regter, Pilatus. Hy is nie oortuig van Jesus se skuld nie, maar laat die proses toe om tog voort te gaan. Dit plaas ' $n$ vraagteken oor die prosedure. Hierdie vraagteken word natuurlik duisend maal groter in die lig van die tweede figuurlike hofsaak wat tegelyk besig was om af te loop.

Volgens die ideologiese perspektief van die verteller vind hierdie hofsaak dus plaas, terwyl daar terselfdertyd ' $n$ ander "figuurlike of metaforiese" hofsaak plaasvind. Die strydvraag in beide hofsake is die identiteit van Jesus: wie is Hy? Dieselfde rolspelers is in beide hofsake betrokke, maar in vergelyking met die vorige figuur verskil hulle respektiewelike plekke en funksies in die onderskeie hofsake. Dit kan so voorgestel word:

${ }^{47}$ Die Hoëprieser en sy raad het Jesus oorhandig aan Pilatus om gekruisig te word op grond van religieuse aanklagte (19:7 en 18:30), maar op die ou einde is Jesus gekruisig op grond van politieke aanklagte $(11: 47-53 ; 19: 12)$. Sien ook Corley $(1992: 848,850)$ en Green (1992:147, 148).

${ }^{48}$ Vergetyk Johannes 18:19-24.

${ }^{49}$ Cassidy (1992:40-41) en Pancaro (1975:308-309) toon korrek aan dat die term "Jode" nie " $n$ vaste kategorie in die Evangelie is nie - hulle behoort verstaan te word as Jesus se opponente.. 


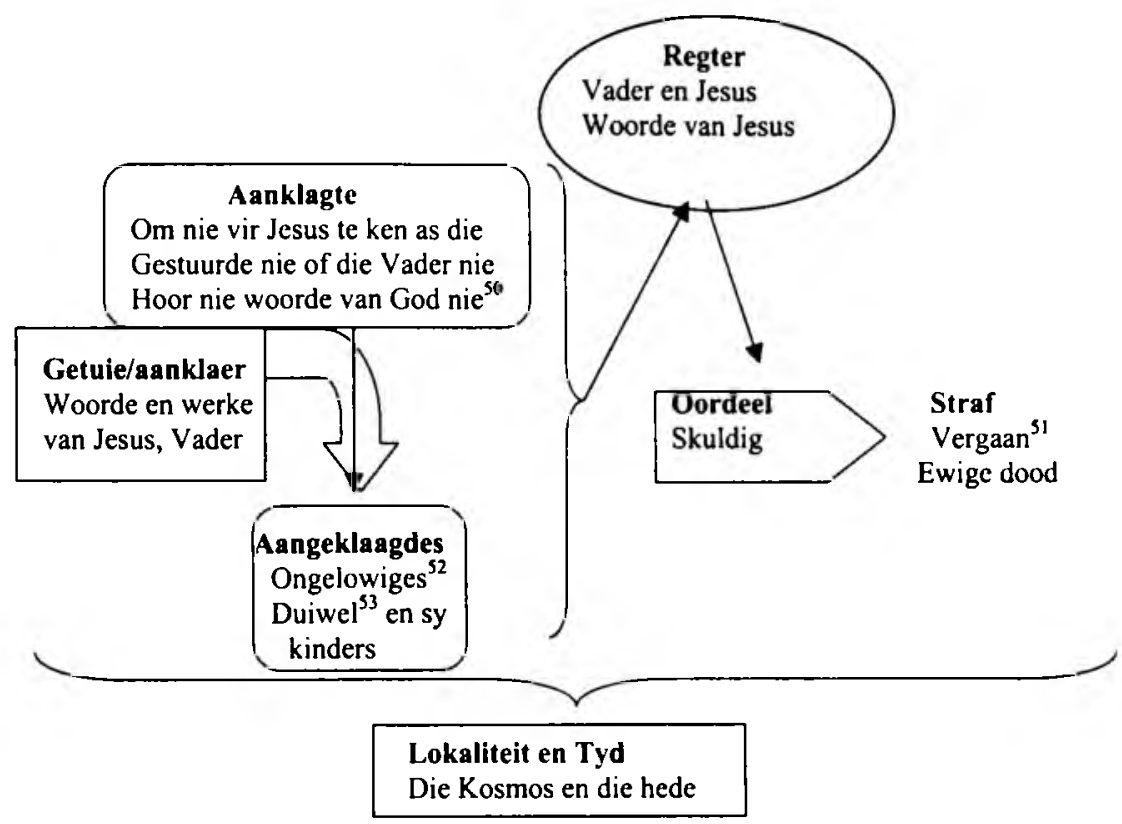

Die verskille is duidelik wanneer die twee hofsake in sitting vergelyk word. Die aanklaers in die eerste figuur word die aangeklaagdes in die tweede figuur en die aangeklaagde in die eerste figuur word die Regter sowel as die Aanklaers in die tweede figuur. Die lokaliteit het verbreed tot die kosmos in die tweede figuur en die tyd tot die hede wat sigself voortdurend realiseer. Die uitslag bly dieselfde: skuldig tot die dood. Die figuurlike hofsaak vind plaas in analogie tot ' $n$ gewone hofsaak, maar tog gelyktydig daarmee.

\section{METAFORIESE BENUTTING VAN FORENSIESE MATERIAAL IN DIE EVANGELIE: 'N DERDE HOFSAAK}

Die analogie tussen ' $n$ gewone hofsaak en die figuurlike een wat hier beskryf word, is duidelik uit bogenoemde voorbeelde. Daar is egter nog ' $n$ derde hofsaak wat sigself afspeel en dit is in die persoon van die geïmpliseerde leser en funksioneer op literêre vlak. Die geïmpliseerde leser ${ }^{54}$ vorm deel van hierdie hofsake wat in die teks afspeel. Die leser word van die

\footnotetext{
${ }^{\text {so }}$ Vergelyk Johannes $8: 47$.

${ }^{51}$ Dit is gelyk aan om nie die ewige lewe te hê nie. Met ander woorde, om nie by God te wees nie.

${ }^{52}$ Ongelowiges sal nie geoordeel word nie (5:24).

${ }^{53}$ Vergelyk Johannes $12: 31 ; 16: 11$.

${ }^{54}$ Van nou af net "leser".
} 
begin van die Evangelie af in die posisie gestel om al die feite op die tafel te hê. In die sin is hy of sy in ' $n$ beter posisie as die Jode. In die verloop van die hofsaak moet die leser dus ook ' $n$ beslissing maak oor wie in die narratief reg is en wie nie. Op die wyse word die keuse eksistensieël bepaald, want ' $n$ keuse in die hofsaak(e) in die loop van die Evangelie is ook ' $n$ keuse oor jouself. Deur die identiteit van Jesus te aanvaar, word ' $n$ mens in ' $n$ spesiale verhouding met Hom ingetrek, wat natuurlik die verkryging van die ewige lewe beteken. Op die wyse bereik die outeur van die Evangelie sy doel soos dit in 20:31 uiteengesit is.

Die beginsels van ' $n$ gewone hofsaak funksioneer ook by hierdie (derde) hofsaak. In ' $n$ hofsaak het ' $n$ mens getuies nodig, maar in hierdie geval is die getuies nie mense nie - dit is die Vader, die dade van Jesus, die Skrif en selfs Jesus self. Nie eers Johannes die Doper kan op hierdie vlak $(5: 33-36)$ ingesluit word nie. Getuies aan die ander kant van die draad is die Jode met hulle (skewe) wetsinterpretasie. Hulle valse motiewe word ook duidelik geskets (11:47-48). Hierdie hofsaak vind plaas binne die grense van die teks self. Die Jode wat nie na Jesus toe wil kom nie $(5: 40)$ wys dat hulle blind is vir die ware realiteit van die hofsaak. Dit is hoekom hulle diegene sal word wat aangekla sal word (5:45-47) en geoordeel sal word. Diegene wat glo sal nie in die oordeel kom nie, maar sal die Ewige Lewe hê (5:24). Met behulp van hierdie getuienis moet die leser die oordeel fel. In 'n sekondêre sin word die leser dus ook in 'n posisie van oordeel geplaas, hoewel die uitslag van die leser nie die waarheid sal bepaal nie. Dit sal alleen maar ' $n$ oordeel oor hom of haarself wees, want dit sal slegs die leser identifiseer met een van die groepe in die narratief"s. Dit is God was sal besluit wat met elke groep gaan gebeur. Die leser word dus so sy of haar eie regter. ' $n$ Negatiewe vonnis deur die leser maak nie van Jesus ' $n$ valse profeet nie, maar maak die een wat so ' $n$ uitslag gee, die aangeklaagde sowel as die een wat oordeel kan verwag. Die regters in die geestelike hofsaak is God, die Vader, en Jesus deur sy boodskap (5:27 gelees saam met 12:48). Die uitslag staan bo enige twyfel vas.

Narratologies kommunikeer die resultate 'n baie kragtige boodskap. Die leser word gekonfronteer met twee keuses: Jesus aan die een kant en die opponente van Jesus aan die ander. Op menslike vlak lyk dit of die mag lê by die opponente, want hulle laat Jesus kruisig, maar op geestelike vlak is dit duidelik dat die mag by Jesus lê. Die leser moet egter ten opsigte van hom of haarself ' $n$ keuse maak. Skematies:

\footnotetext{
${ }^{55}$ Forensiese elemente word retoriese benut om ' $n$ beslissing oor die identiteit van Jesus aan te moedig. Denkbeeldige hofsake word aangebied om die kommunikasie van Johannesevangelie se boodskap te versterk. Dit wil die leser tot ' $\mathrm{n}$ beslissing lei ( $\mathrm{Vg}$ ! Harvey 1976:122).
} 


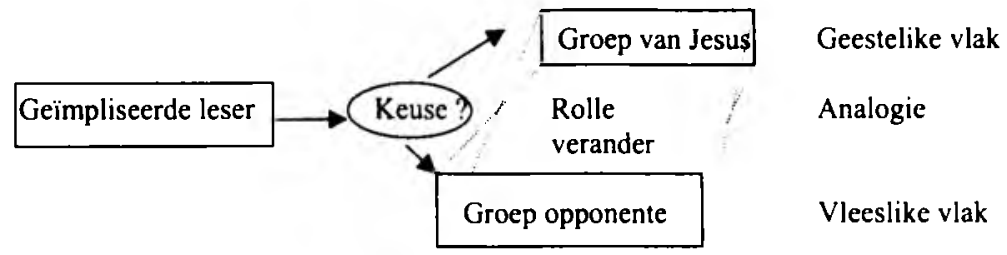

\section{SAMEVATTING}

Soos hierbo geïllustreer, is die forensiese vergelyking in hierdie Evangelie kompleks, nie alleen as gevolg van die dinamika van die metafoor wat betrokke is nie, maar ook as gevolg van retoriese dimensie waardeur die leser aangemoedig word om ' $n$ keuse te maak. Die vergelyking sluit feitlik al die elemente in wat nodig is vir ' $n$ gewone hofsaak. Deur middel van " $n$ analogie word die kosmiese hofsaak voorgestel, en dit loop parallel aan die fisiese hofsaak van Jesus voor Pilatus. Baie elemente is gemetaforiseer, byvoorbeeld die getuies, die regters asook die beskuldigdes. Daar is ' $n$ Regter, maar Hy is die hemelse Koning. Die getuies, die aanklaers sowel as die aangeklaagdes is hier teenwoordig, daar is verhore en verdedigings, sowel as vonnisse. Hierdie elemente is almal op 'n analogiese manier aangewend as deel van die forensiese vergelykings.

Die basiese literêre oogmerk van die Johannese narratief kom pertinent tot uitdrukking in die metaforisering van die forensiese elemente. Op die manier word ' $n$ uitnoding tot die leser gerig: Aan wie se kant staan jy? - aan die kant van die aangeklaagde Jesus, of aan die kant van die aardse aanklaers? Wie Jesus is, sy identiteit en status moet jou besluit bepaal. Dit is wat op die spel was in die hofsaak(e) in die Evangelie. Op hierdie manier word nie alleen die goddelike waarhede nie, maar ook elke leser van die Evangelie verhoor.

\section{Literatuurverwysings}

Ashton, J 1991. Understanding the Fourth Gospel. Oxford: Clarendon.

Barrett, C K 1978. The Gospel according to St. John. $2^{\text {nd }}$ ed. London: SPCK.

Blank, J 1964. Krisis. Untersuchungen zur johanneischen Christologie und Eschatologie. Freiburg: Breisgau.

Blinzler, J 1961. The Trial of Jesus. $3^{\text {rd }}$ ed. Cork: Mercier.

Brown, R E 1971. The Gospel according to John (i-xii), vol l. New York: Doubleday.

Bultmann, R 1978. Das Evangelium des Johannes. Gơttingen: Vandenhoeck und Ruprecht.

Cassidy, R J 1992. John's Gospel in New Perspective. New York: Orbis Books.

Catchpole, D R 1971. The Trial of Jesus. London: E.J. Brill. 
Corley, B 1992. Trial of Jesus, in Green, J B \& McKnight, S (eds), Dictionary of Jesus and the Gospels, 841-854. England: InterVarsity.

Davies, M 1992. Rhetoric and Reference in the Fourth Gospel. England: JSOT.

Duke, P D 1985. Irony in the Fourth Gospel. Atlanta: John Knox.

Green, J B 1992. Death of Jesus, in Green, J B \& McKnight, S (eds), Dictionary of Jesus and the Gospels, 147-163. England: InterVarsity.

Harvey, A E 1976. Jesus on trial: A study in the Fourth Gospel. London: SCM.

Hoehner, H W 1992. Pontius Pilate, in: Green, J B \& McKnight, S (eds), Dictionary of Jesus and the Gospels, 615-617. England: InterVarsity.

Mafico, T L J 1997. Judge, judging, in: Freedman, D N (ed), The Anchor Bible Dictionary, Logos online. New York: Doubleday.

Malina, B J \& Rohrbaugh, R L 1998. Social-Science Commentary on the Gospel of John. Minneapolis: Fortress.

-, 1993. The New Testament World. Insights from cultural anthropology. Atlanta: John Knox.

Moloney, F J 1998. The Gospel of John. Minneapolis: Fortress.

Morris, L 1974. The Gospel according to John. Grand Rapids: W B Eerdmans.

Newman, B M \& Nida, E A 1980. A Translators' handbook on the Gospel of John. London: United Bible Societies.

Neyrey, J H 1996. The trials (forensic) and tribulations (honor challenges) of Jesus: John 7 in social science perspective. BTB 26(3), 107-124.

,- 1987 . Jesus the Judge:Forensic process in John 8:21-59. Biblica 68, 509-542.

Pancaro, S 1975. The Law in the Fourth Gospel. Leiden: E J Brill.

Schnackenburg, R 1982. The Gospel According to John. New York: Crossroad.

Schneider, W 1992 Judgment, Judge, Deliver, Judgment seat, in Brown, C (gen ed), The New International Dictionary of the New Testament Theology, vol 2, England: Paternoster.

Sherwin-White, A N 1963. Roman Society and Roman Law in the New Testament. Oxford: Oxford University.

Stewart, A 1936. The Supreme Claim. EvQ 8, 423-433.

Stibbe, M W G 1993. John. England: JSOT.

Thompson, M M 1992. John, the Gospel of, in: Green, J B \& McKnight, S (eds), Dictionary of Jesus and the Gospels, 368-383. England: InterVarsity.

Travis, S H 1992. Judgement, in: Green, J B \& McKnight, S (eds), Dictionary of Jesus and the Gospels, 408-411. England: InterVarsity.

Turner, M M B 1992. Holy Spirit, in Green, J B \& McKnight, S (eds), Dictionary of Jesus and the Gospels, 341-351. England: InterVarsity.

Van der Watt, J G 2000. The Family and the King. Dynamics of metaphor in the Gospel according to John. Leiden: E J Brill. 